\title{
The influence of heat loss from pipes in an unheated basement on the heating energy consumption of an entire typical apartment building
}

\author{
Anti Hamburg ${ }^{1, *}$, Targo Kalamees ${ }^{2,1}$ \\ ${ }^{1}$ Department of Civil Engineering and Architecture, Tallinn University of Technology, Tallinn, Estonia \\ ${ }^{2}$ Smart City Center of Excellence (Finest Twins), Tallinn University of Technology, Tallinn, Estonia
}

\begin{abstract}
The majority of old apartment buildings were designed with an unheated basement. Building service systems such as district heating heat exchangers and pipes for domestic hot water and for space heating are usually located in this unheated basement. In addition, these locations are connected with shafts. All these pipe's heat losses increase air temperature in the basement. If these losses are included into the building energy balance, then they decrease heat loss through the basement ceiling. The basement's heat balance is also dependent on heat loss from the basement envelope and outdoor air exchange in the basement. In early stages of design, designers and energy auditors need rough models to make decisions in limited information conditions. Once the effects of heat losses from pipes become apparent, they need to be factored into the buildings energy balance, and their effects on heat loss through the basement ceiling needs to be calculated. In this paper we analyse the effect these heat losses have on the service system's heat gains and heat loss through an uninsulated basement ceiling at different basement insulation levels and with different thicknesses of pipe insulation. From our study we found that pipe losses in the basement increase the building energy performance value by at least $4 \mathrm{kWh} /\left(\mathrm{m}^{2} \cdot \mathrm{a}\right)$ and their impact on a renovated apartment building is very important.
\end{abstract}

\section{Introduction}

Improving the energy performance of buildings is a tool to meet the long-term energy saving and decarbonisation goals of the European Union. In the EU, residential buildings accounted for $27 \%$ of energy use and the main use of this energy (64\%) by households is for heating their homes [1]. The net energy need for space depends quite linearly on the specific heat loss of the building envelope [2] therefore thermal improvement of the building envelope is one of the most needed renovation measures for old apartment buildings in cold climates [3-5].

Deep energy renovation reduces ca $70 \%$ of delivered energy need and ca $60 \%$ of primary energy need [6]. Unfortunately, the calculated energy saving is often much more optimistic than the measured savings show [7-10]. The behaviour of occupants has been identified as one of the main causes for difference between predicted and real energy use $[11,12]$. Nevertheless, construction quality $[13,14]$ and calculation or measurement methods $[15,16]$ also influence the predicted and real energy use.

The majority of old apartment buildings in Estonia were designed and constructed with an unheated cellar or basement. Temperature in the basement depends on heat loss from the building envelope of the basement, heat gains from the first floor and heat loss from the service systems. As lower temperatures prevail in unheated basements, thermal separation of the basement from the heated part of the building is necessary but because of low ceiling height of basements, in most cases it is complicated.

In the detailed design stage, heat loss calculations through the basement ceiling are modelled by software or calculated by standard EN ISO 13370 [17]. In the early stage of design, designers and energy auditors need rough models to make decisions in limited information conditions.

Once the effects of heat losses from pipes become apparent, they need to be factored into the buildings energy balance, and their effects on heat loss through the basement ceiling needs to be calculated. In this paper we analyse the effect these have service system's pipes heat gains and heat loss through an uninsulated basement ceiling at different basement insulation levels: basement walls are well insulated, partly insulated or uninsulated and at different insulation levels of the service systems.

\footnotetext{
${ }^{*}$ Corresponding author: anti.hamburg@taltech.ee
} 


\section{Methods}

\subsection{Reference building}

Our analysis is based on the reference building which represents the most built common apartment building type from 1960-90's (see Fig 1. ). The building is a 5-story large concrete panel apartment building with a total heated area $3562 \mathrm{~m}^{2}$, constructed in 1986 .

Because of serious thermal bridges in these type of non-renovated buildings [13], mould growth was present on interior surfaces, especially in the corners of exterior walls and roof before renovation, and the thermal transmittance of the external envelope was $U=0.9-1.1 \mathrm{~W} /\left(\mathrm{m}^{2} \cdot \mathrm{K}\right)$. The energy need for heating and domestic hot water was close to $300 \mathrm{kWh} /\left(\mathrm{m}^{2} \cdot \mathrm{a}\right)$. The building had insufficient ventilation, it was subject to overheating during winter and provided unsatisfactory thermal comfort. The reference building was renovated in 2017 according to nZEB criteria (class A, $\left.\mathrm{EPV} \leq 100 \mathrm{kWh} /\left(\mathrm{m}^{2} \cdot \mathrm{a}\right)\right)$ by means of prefabricated timber frame wall and roof insulation elements [18-20].
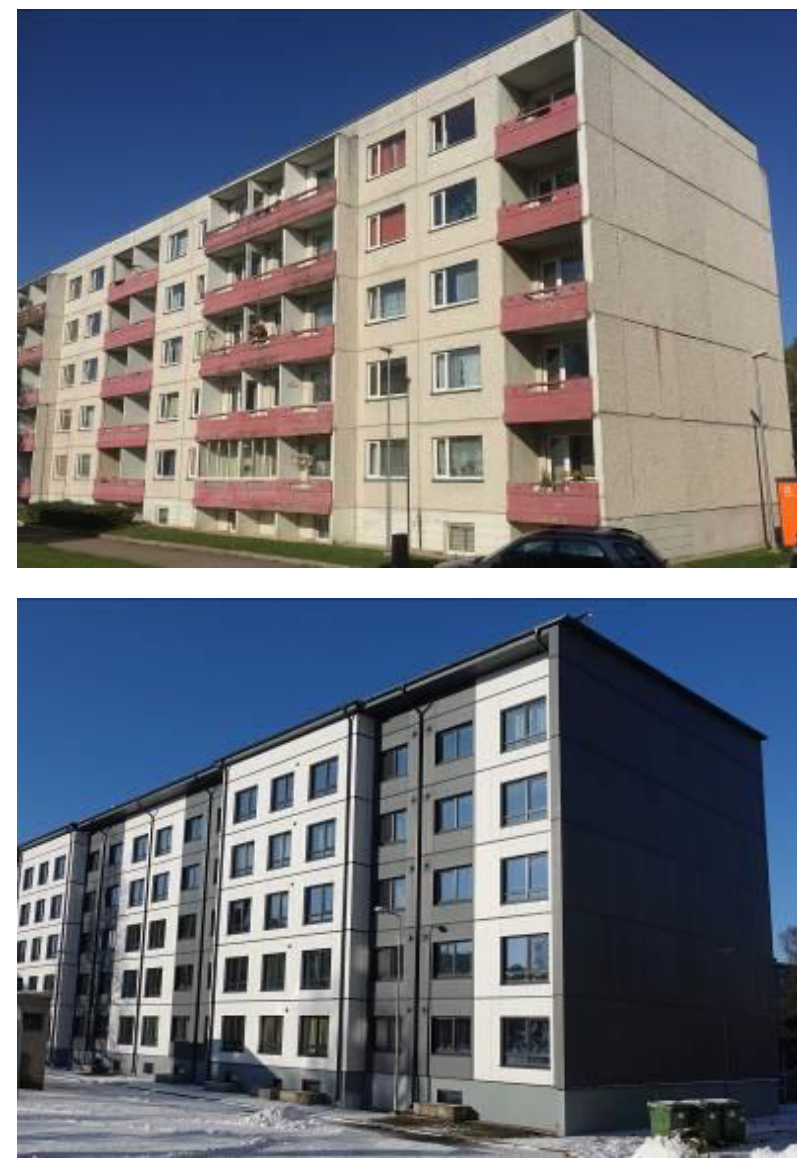

Fig 1. Overview of the reference building in 2015 before (above) and in winter 2017 after (below) the nZEB renovation.

\subsection{Heat balance model}

Heat balance in a basement depends on heat flow through the basement envelopes (Fig. 2) and air exchange. On the other hand, a basement gets heat from apartments (heat flow through basement ceiling $\left(U_{r}\right)$ ), and heat gain from the sun through basement windows. During the 1980's, the typical basement ceiling $\left(U_{r}\right)$ thermal transmittance was, on average, $1.4 \mathrm{~W} /\left(\mathrm{m}^{2} \cdot \mathrm{K}\right)$. Typical construction was a concrete floor insulated with $26 \mathrm{~mm}$ cellulose plates, overlaid with $20 \mathrm{~mm}$ chipboard plates with a parquet covering.

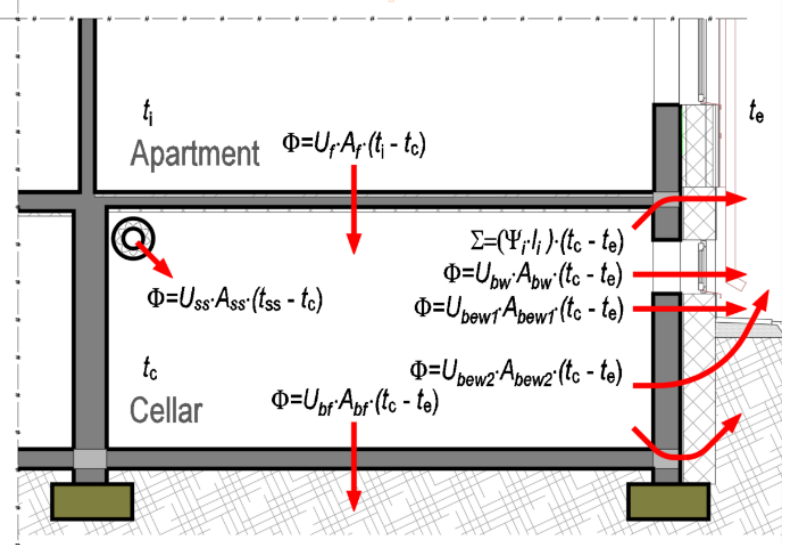

Fig 2 Heat balance of basement of an apartment building.

\subsection{Simulations}

The indoor climate and energy performance was simulated using the energy and indoor climate simulation program IDA Indoor Climate and Energy [21,22]. This software allows the modelling of a multi-zone building, internal heat gains and external solar loads, outdoor climate, heating and ventilation systems, dynamic simulation of heat transfer and air flows. This software is validated [23-25], and the building model is calibrated against field measurements [26].

The energy performance of buildings is assessed based on primary energy use, expressed by the energy performance value $\operatorname{EPV~}\left(\mathrm{kWh} /\left(\mathrm{m}^{2} \cdot \mathrm{a}\right)\right)$ of a whole building (i.e. heating, cooling, ventilation, DHW, lighting, HVAC auxiliary, appliances) according to Estonian legislation $[27,28]$. The following energy performance criterions were used where the weighting factor for district heating is 0.9 and for electricity is 2.0 :

- $\mathrm{nZEB}$ renovation, EPV $\leq 105 \mathrm{kWh} /\left(\mathrm{m}^{2} \cdot \mathrm{a}\right)$ (class A):

○ $U_{\text {bew } 1}=0.13 \mathrm{~W} /\left(\mathrm{m}^{2} \cdot \mathrm{K}\right)(250 \mathrm{~mm}$ of insulation $)$,

○ $U_{\text {bew } 2}=0.08 \mathrm{~W} /\left(\mathrm{m}^{2} \cdot \mathrm{K}\right)(250 \mathrm{~mm}$ of insulation $)$,

○ $U_{\mathrm{bf}}=0.36 \mathrm{~W} /\left(\mathrm{m}^{2} \cdot \mathrm{K}\right)(0 \mathrm{~mm}$ of insulation $)$,

○ $U_{\mathrm{w}}=1.0 \mathrm{~W} /\left(\mathrm{m}^{2} \cdot \mathrm{K}\right)$ (triple glazing),

nZEB renovated buildings should have also local energy production, without production EPV should be $\leq 105 \mathrm{kWh} /\left(\mathrm{m}^{2} \cdot \mathrm{a}\right)$.

- Low energy building renovation, $\mathrm{EPV} \leq 150$ $\mathrm{kWh} /\left(\mathrm{m}^{2} \cdot \mathrm{a}\right)($ class $\mathrm{C})$,

○ $U_{\text {bew } 1}=0.17 \mathrm{~W} /\left(\mathrm{m}^{2} \cdot \mathrm{K}\right)(200 \mathrm{~mm}$ of insulation $)$,

○ $U_{\text {bew } 2}=0.20 \mathrm{~W} /\left(\mathrm{m}^{2} \cdot \mathrm{K}\right)(150 \mathrm{~mm}$ of insulation $)$,

○ $U_{\mathrm{bf}}=0.38 \mathrm{~W} /\left(\mathrm{m}^{2} \cdot \mathrm{K}\right)(0 \mathrm{~mm}$ of insulation $)$,

○ $U_{\mathrm{w}}=1.0 \mathrm{~W} /\left(\mathrm{m}^{2} \cdot \mathrm{K}\right)$ (triple glazing),

- Renovation as usual (2015-2019), $\mathrm{EPV} \leq 180 \mathrm{kWh} /\left(\mathrm{m}^{2} \cdot \mathrm{a}\right)$ (class D),

○ $U_{\text {bew } 1}=0.22 \mathrm{~W} /\left(\mathrm{m}^{2} \cdot \mathrm{K}\right)(150 \mathrm{~mm}$ of insulation $)$,

○ $U_{\text {bew } 2}=0.39 \mathrm{~W} /\left(\mathrm{m}^{2} \cdot \mathrm{K}\right)(100 \mathrm{~mm}$ of insulation $)$,

○ $U_{\mathrm{bf}}=0.39 \mathrm{~W} /\left(\mathrm{m}^{2} \cdot \mathrm{K}\right)(0 \mathrm{~mm}$ of insulation $)$, 
○ $U_{\mathrm{w}}=1.2 \mathrm{~W} /\left(\mathrm{m}^{2} \cdot \mathrm{K}\right)$ (double glazing half changed with triple glazed windows),

- Renovation as usual before 2014, $\mathrm{EPV} \leq 220 \mathrm{kWh} /\left(\mathrm{m}^{2} \cdot \mathrm{a}\right)$ (class $\left.\mathrm{E}\right)$,

○ $U_{\text {bew } 1}=0.22 \mathrm{~W} /\left(\mathrm{m}^{2} \cdot \mathrm{K}\right)(150 \mathrm{~mm}$ of insulation $)$,

$U_{\text {bew } 2}=0.61 \mathrm{~W} /\left(\mathrm{m}^{2} \cdot \mathrm{K}\right)(0 \mathrm{~mm}$ of insulation $)$,

$U_{\mathrm{bf}}=0.39 \mathrm{~W} /\left(\mathrm{m}^{2} \cdot \mathrm{K}\right)(0 \mathrm{~mm}$ of insulation $)$,

○ $U_{\mathrm{w}}=1.2 \mathrm{~W} /\left(\mathrm{m}^{2} \cdot \mathrm{K}\right)$ (double glazing, half changed with triple glazed windows),

- not renovated, EPV $\leq 280 \mathrm{kWh} /\left(\mathrm{m}^{2} \cdot \mathrm{a}\right)$ (class F),

○ $U_{\text {bew } 1}=1.0 \mathrm{~W} /\left(\mathrm{m}^{2} \cdot \mathrm{K}\right)(0 \mathrm{~mm}$ of insulation $)$,

○ $U_{\text {bew } 2}=0.61 \mathrm{~W} /\left(\mathrm{m}^{2} \cdot \mathrm{K}\right)(0 \mathrm{~mm}$ of insulation $)$,

○ $U_{\mathrm{bf}}=0.39 \mathrm{~W} /\left(\mathrm{m}^{2} \cdot \mathrm{K}\right)(0 \mathrm{~mm}$ of insulation $)$,

○ $U_{\mathrm{w}}=1.7 \mathrm{~W} /\left(\mathrm{m}^{2} \cdot \mathrm{K}\right)$ (2-pane glazing mainly changed between 2000-2010).

In all simulations the air changes in the basement were $0.15 \mathrm{l} /\left(\mathrm{s} \cdot \mathrm{m}^{2}\right)$. In the figures, EPV classes by class symbols (A, C, D, E and F).

\subsection{Service system pipes}

For thermal insulation of service systems, being domestic hot water pipes (DHW), DHW circulation pipes (Circ.) and heating pipes in the basement, we use the following levels:

- Well insulated pipes (40 $\mathrm{mm}$ thermal insulation)

- Average insulated pipes (20 $\mathrm{mm}$ thermal insulation)

- No extra thermal isolation

Pipe length of heating distribution pipes (equation 1), DHW (equation 2) and Circ. (equation 3) in the basement are calculated with standard EN-15316-3 [29]. In equations $\mathrm{L}_{\mathrm{L}}$ is length and $\mathrm{L}_{W}$ is width of the building.

$$
\begin{gathered}
2 \cdot L_{L}+0.01625 \cdot L_{L} \cdot L_{w}{ }^{2},(\mathrm{~m}) \\
L_{L}+0.0625 \cdot L_{L} \cdot L_{w},(\mathrm{~m}) \\
2 \cdot L_{L}+0.0125 \cdot L_{L} \cdot L_{w},(\mathrm{~m})
\end{gathered}
$$

\begin{tabular}{|c|}
\hline $\begin{array}{l}\text { - } \text { DHW } \\
\text { - } \quad \text { Circ. } \\
\text { - }\end{array}$ \\
\hline
\end{tabular}

Outer diameter of pipes in the basement in all simulations:

Pipes linear thermal transmittances is also calculated by standard EN 15316-3 (4).

$$
\Psi=\frac{\pi}{\frac{1}{2 \cdot \lambda_{p}} \cdot \ln \frac{d_{i}}{d_{p}}+\frac{1}{2 \cdot \lambda_{D}} \cdot \ln \frac{d_{a}}{d_{i}}+\frac{1}{h_{a} \cdot d_{a}}}, \mathrm{~W} /(\mathrm{m} \cdot \mathrm{K})
$$

Thermal transmittances from service system pipes are shown in Table 1.
Table 1. Pipes linear thermal transmittances.

\begin{tabular}{|c|c|c|c|}
\hline $\begin{array}{c}\text { Thermal } \\
\text { isolation }\end{array}$ & DHW & Circ. & Heating \\
\hline $\mathrm{mm}$ & \multicolumn{3}{|c|}{$\Psi(\mathrm{W} / \mathrm{m} \cdot \mathrm{K})$} \\
\hline 40 & 0.22 & 0.16 & 0.17 \\
\hline 20 & 0.33 & 0.21 & 0.24 \\
\hline 0 & 1.22 & 0.62 & 0.77 \\
\hline
\end{tabular}

We decided to use a slightly different approach compared to standard EN 15316-3 [29]:

- In our simulations we use a basement temperature as shown in our basic simulations.

When our assumed heat gain to the room from pipes differed by more than $0.1 \mathrm{~W} / \mathrm{m}^{2}$ (calculated using average temperature from November until March) we made a fresh calculation.

- In our case study building, the length of heating pipes are 77 meter longer than calculations showed but we decided to use length which is calculated by standard

- We focused only on pipe heat losses in an unheated basement.

Pipe losses in shafts and apartments are not calculated.

- Pipes linear thermal transmittances are calculated as reference building average pipe sizes after nZEB renovation.

To compare results, we used the same pipe sizes in all simulation cases.

\section{Results}

\subsection{Service system pipe length and heat loss}

Heat loss through pipes depends on the pipes inner flow temperature and also the outside temperature. In all simulations we used an inner flow temperature for DHW of $55^{\circ} \mathrm{C}$, Circ. $52^{\circ} \mathrm{C}$ and Heating $40^{\circ} \mathrm{C}$ (from 15 of April until 15 of October $30^{\circ} \mathrm{C}$ ). Basement temperature depends on the balance of heat losses and heat gains in the basement. In our basic simulation we attempted to provide for this by making the calculations without pipe heat losses and then assuming a figure for pipe heat loss with which to adjust the final temperature calculation. This was clearly not a preferred approach and our solution was to make detailed model for this.

Pipes length in basement by standard EN-15316-3:
- DHW
$112 \mathrm{~m}$
- Circ.
$126 \mathrm{~m}$
- Heating pipes $329 \mathrm{~m}$

Compared to the reference building, DHW pipes are $5 \mathrm{~m}$ longer in length, Circulation pipes $19 \mathrm{~m}$ longer and Heating pipes $77 \mathrm{~m}$ shorter. Which means that heat losses in the reference building are, with the same thermal insulation, greater.

From the length and thermal transmittance of the pipes, the pipes inner temperature and the estimated 
basement temperature we calculate the pipes heat losses to the basement (Table 2).

Table 2. Pipe heat losses in basement in different simulation cases.

\begin{tabular}{|c|c|c|}
\hline \multirow{2}{*}{$\begin{array}{l}\text { Simulation } \\
\text { model } \\
\text { according to } \\
\text { buildings } \\
\text { energy } \\
\text { performance } \\
\text { certificate }\end{array}$} & $\begin{array}{l}\text { Pipes insulation in } \\
\text { basement }\end{array}$ & $\begin{array}{l}\text { Pipe heat loss } \\
\text { to basement in } \\
\text { heating period }\end{array}$ \\
\hline & $\mathrm{mm}$ & $\mathrm{W} / \mathrm{m}^{2}$ \\
\hline \multirow[t]{4}{*}{ A } & no heat loss from pipes & 0 \\
\hline & 40 & 4.0 \\
\hline & 20 & 5.4 \\
\hline & 0 & 14.4 \\
\hline \multirow[t]{4}{*}{$\mathrm{C}$} & no heat loss from pipes & 0 \\
\hline & 40 & 4.0 \\
\hline & 20 & 5.5 \\
\hline & 0 & 15.0 \\
\hline \multirow[t]{4}{*}{$\mathrm{D}$} & no heat loss from pipes & 0 \\
\hline & 40 & 4.1 \\
\hline & 20 & 5.7 \\
\hline & 0 & 15.5 \\
\hline \multirow[t]{4}{*}{$\mathrm{E}$} & no heat loss from pipes & 0 \\
\hline & 40 & 4.1 \\
\hline & 20 & 5.6 \\
\hline & 0 & 15.4 \\
\hline \multirow[t]{4}{*}{$\mathrm{F}$} & no heat loss from pipes & 0 \\
\hline & 40 & 4.1 \\
\hline & 20 & 5.8 \\
\hline & 0 & 15.5 \\
\hline
\end{tabular}

From 15 of April until 15 of October pipe heat losses are $70 \%$ of heating season losses. Recalculations with simulated temperature outside of heating season showed that in all cases it is between $65 \%$ until $70 \%$ which mean this assumption is more or less the same.

\subsection{Influence of pipe heat loss on temperature in the basement and heat flow through the basement's ceiling}

Our calculations with different EPV classes for the building with different thickness of thermal insulation on pipes showed that, without involving pipes in the calculations, the average temperature in the basement (between 16 of October until 14 of April) in the base cases is between $11^{\circ} \mathrm{C}$ and $12.7^{\circ} \mathrm{C}$. When pipes are not insulated, there could be a basement temperature rise of up to $22.3^{\circ} \mathrm{C}$ in cases where the basement envelopes are well insulated. In other cases, the basement temperature without pipe insulation was $20^{\circ} \mathrm{C}$ or $21^{\circ} \mathrm{C}$. In cases where pipes are insulated with $20 \mathrm{~mm}$ or $40 \mathrm{~mm}$ thick insulation we can see in Fig. 3 that the average temperature is between $13.8^{\circ} \mathrm{C}$ and $16.3^{\circ} \mathrm{C}$. In this section we can see that when basement envelopes are not insulated, then heat flow through the basement ceiling is more than $8 \mathrm{~W} / \mathrm{m}^{2}$ which is comparable with the base case basement where there are no pipes and envelopes are well insulated.

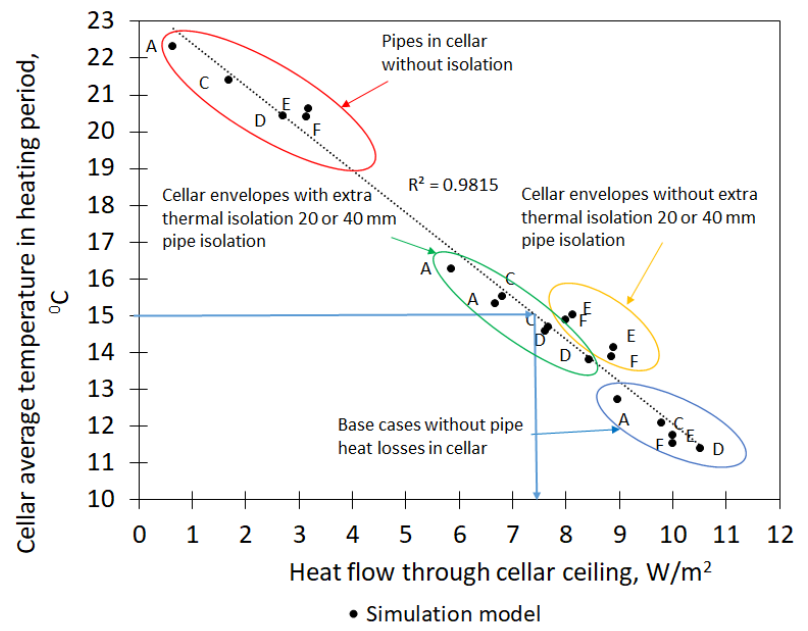

Fig 3. Basement average temperature between 16 of October until 14 of April compared with heat flow from basement ceiling in different simulation cases.

Service system pipes annual heat losses per heated area compared with heat flow through basement ceiling are presented in Figure 4. Here we can see that delivered energy growth is directly connected with pipe insulation. Without thermal insulation, delivered energy is, in all cases, on average $27 \mathrm{kWh} /\left(\mathrm{m}^{2} \cdot \mathrm{a}\right)$ but heat flow through the basement ceiling depends on how well insulated are the basement envelopes. With $20 \mathrm{~mm}$ or $40 \mathrm{~mm}$ pipe insulation, the pipe losses delivered energy of between 7 to $10.5 \mathrm{kWh} /\left(\mathrm{m}^{2} \cdot \mathrm{a}\right)$, and variation in the ceiling heat flow is the same as cases where pipes are not insulated. 


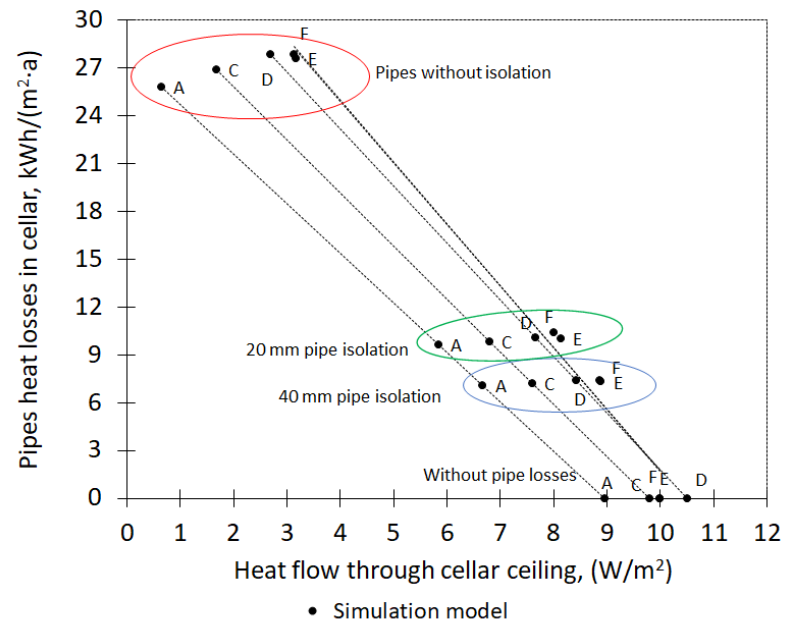

Fig 4. Service system pipes annual heat losses per heated area compared with heat flow through basement ceiling.

\subsection{The influence of pipes heat loss to delivered heating energy}

Fig. 5 shows how the pipes annual heat losses influence the entire building heating energy need. This is caused by a decrease of the basement ceiling energy loss. If the pipes annual heat loss is $7 \mathrm{kWh} /\left(\mathrm{m}^{2} \cdot \mathrm{a}\right)$ than the increase in the entire heating energy is, on average, $4.5 \mathrm{kWh} /\left(\mathrm{m}^{2} \cdot \mathrm{a}\right)$, however, when pipes are not insulated the difference is greater. With a $27 \mathrm{kWh} /\left(\mathrm{m}^{2} \cdot \mathrm{a}\right)$ annual heat loss from the pipes, this increase in entire delivered heating energy is, on average, $17 \mathrm{kWh} /\left(\mathrm{m}^{2} \cdot \mathrm{a}\right)$.

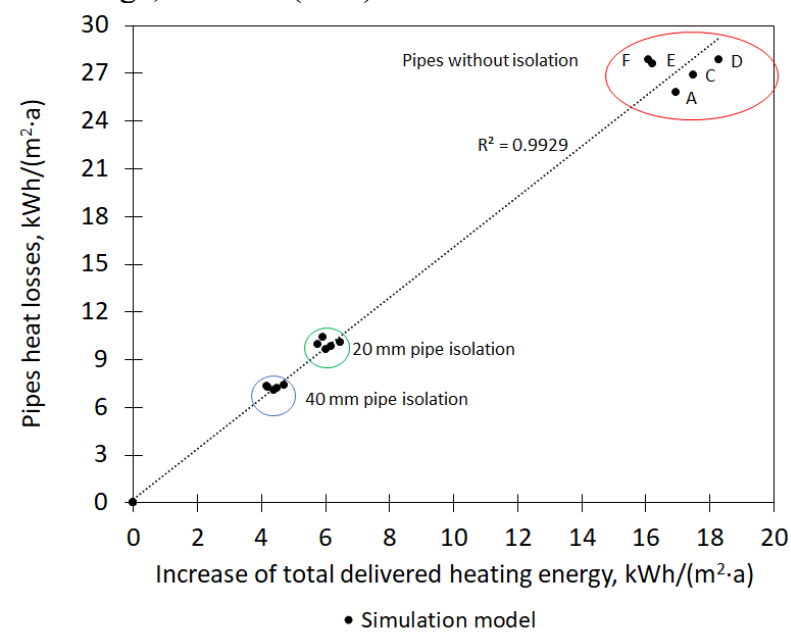

Fig 5. Service system pipes annual heat losses per heated area compared with building total delivered heating energy increase.

From this we can say that $10 \mathrm{kWh} /\left(\mathrm{m}^{2} \cdot \mathrm{a}\right)$ of heating energy is utilised. Looking deeper at all cases, we can say that the average decrease of building total delivered heating and ventilation heat energy is greater when the losses from service system pipes in the basement are greater. In Fig. 6 we show that, in buildings with better envelope insulation, the decrease is lower compared to buildings where the basement envelopes are not insulated, but the increase in total heating energy is more or less the same with different pipe insulation thicknesses.

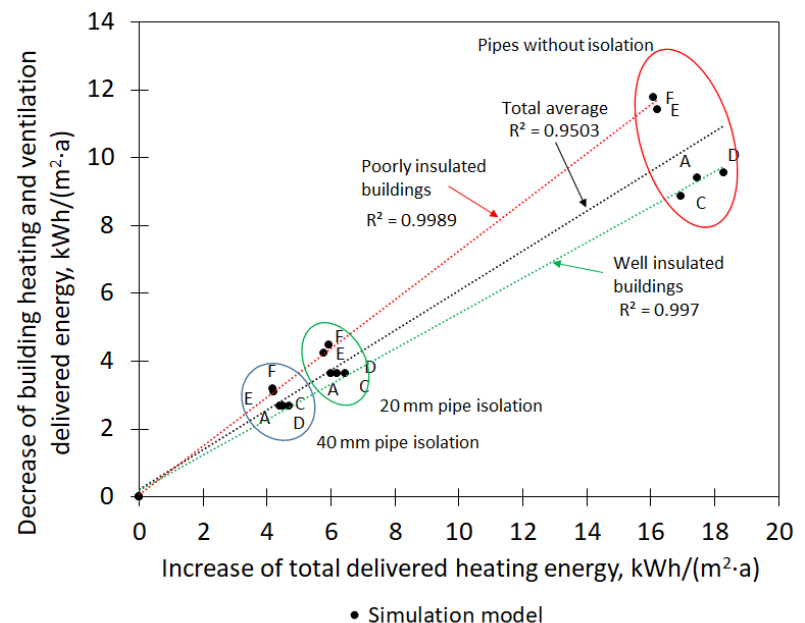

Fig 6. Decrease of building delivered heating and ventilation heat energy compared with building total delivered heating energy increase.

Fig 7. shows the building models total delivered heating energy consumption with basement pipe losses compared to the pipe losses proportional share of this loss. If the building is not renovated, or the building is renovated as EPV class E, then, with insulated pipes, this proportional loss is up to $9 \%$ of the entire delivered energy, and with un-insulated pipes, up to $22 \%$. When pipes are insulated and our delivered energy for the entire heating is less than $60 \mathrm{kWh} /\left(\mathrm{m}^{2} \cdot \mathrm{a}\right)$, in line with apartment buildings that are renovated today, then pipe losses can be up to $33 \%$ of the entire heating energy losses.

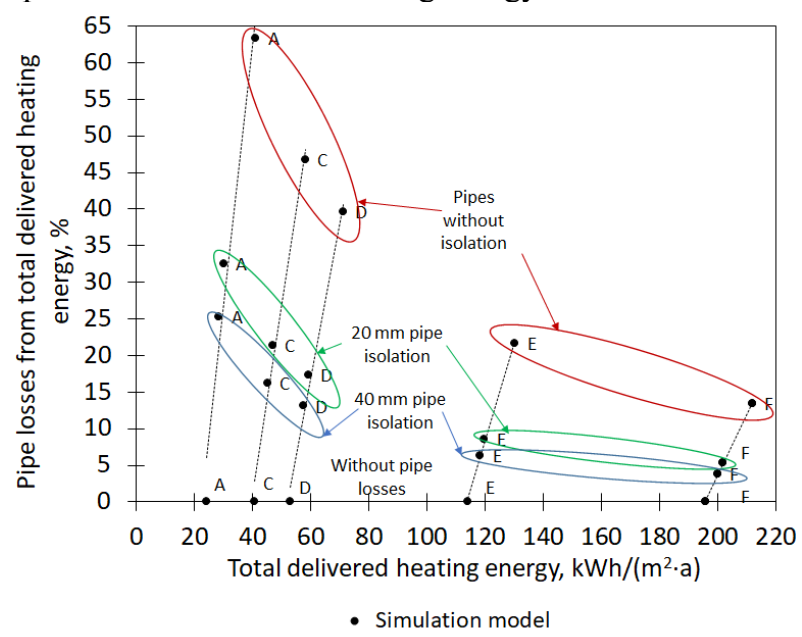

Fig. 7. Building models total delivered heating energy consumption with basement pipe losses compared with pipe losses from total delivered heating energy.

\subsection{Energy performance value change and basement temperature}

If pipe heat losses with insulated service system pipes is, on average, a 3.8 to $5.8 \mathrm{kWh} /\left(\mathrm{m}^{2} \cdot \mathrm{a}\right)$ increase in total delivered heating energy, then it is also an increase in the total primary energy consumption (EPV). In Fig. 8 we can 
see that the increase of primary energy consumption with well insulated pipes is $4 \mathrm{kWh} /\left(\mathrm{m}^{2} \cdot \mathrm{a}\right)$, and with $20 \mathrm{~mm}$ insulated pipes averages $5.5 \mathrm{kWh} /\left(\mathrm{m}^{2} \cdot \mathrm{a}\right)$. In existing buildings, this means up to a $2 \%$ increase and in nZEB buildings an increase of up to $4.3 \%$.

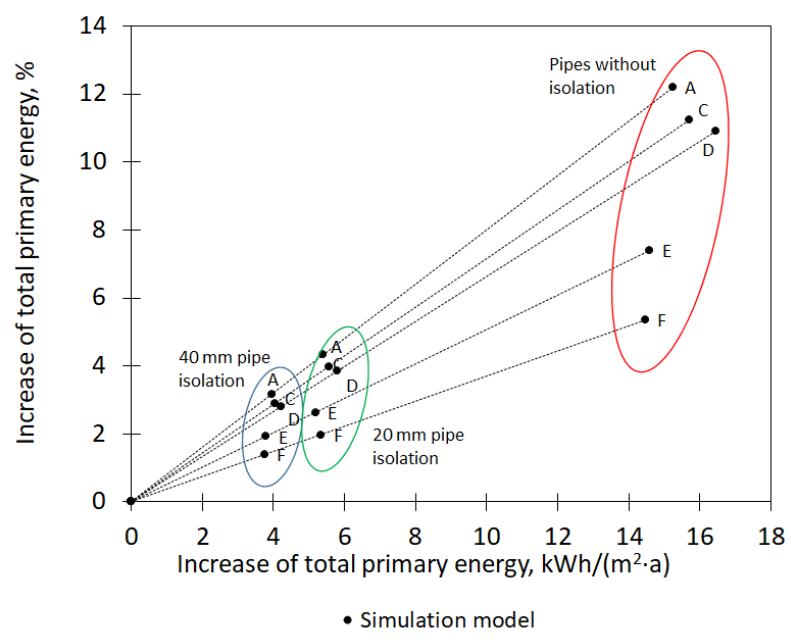

Fig 8. Increase of total primary energy

Comparing primary energy change with average basement temperature (Fig. 9) we can see that in an nZEB building with $20 \mathrm{~mm}$ pipe insulation, the EPV is 5.3 $\mathrm{kWh} /\left(\mathrm{m}^{2} \cdot \mathrm{a}\right)$ greater than our base case and the basement average temperature is $16.2^{\circ} \mathrm{C}$.

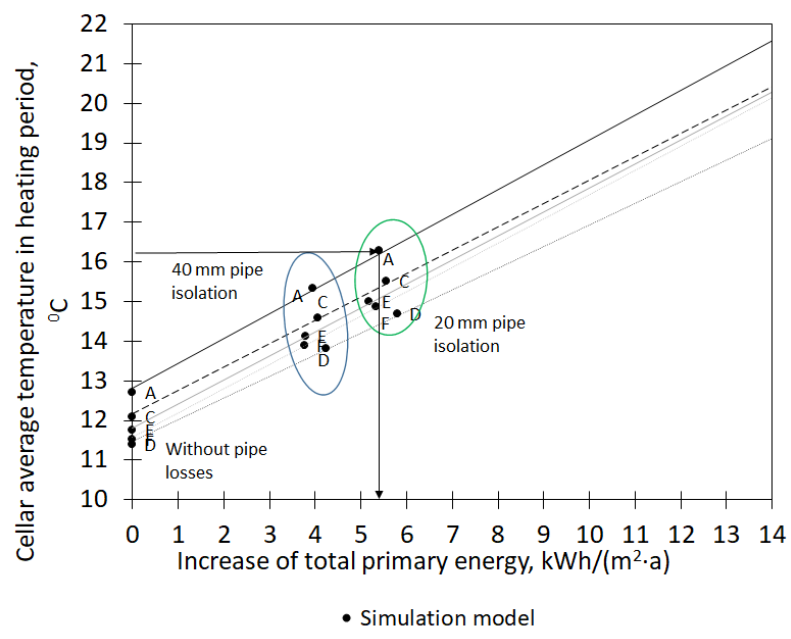

Fig 9. Basement average temperature between 16 of October until 14 of April compared with the increase in total primary energy.

\section{Discussion}

This study focused on the effect of pipe heat losses on the entire building energy consumption. As typical Estonian apartment buildings have unheated basements, then for energy calculations, we calculated this as an unheated zone without internal heat gains. In existing situations there exist losses from pipes. In the Estonian energy efficiency calculation method [30] we don't calculate pipe losses as a part of the energy performance number. This differs from the German calculation approach. The
German standard for calculating energy efficiency of buildings [31] uses the same calculation method for calculating pipe losses as we used in our case studies. However, the German standard also calculates heat losses from pipes in shafts and in apartments.

The standard EN 15316-3 [29] says that in unheated basements, the temperature used in calculations is $13^{\circ} \mathrm{C}$ and our simulations showed that the average temperature between December until the end of February is, on average, more or less the same, but in buildings with good thermal insulation it is higher even if service pipes are well insulated. If pipe insulation is poor, then heat losses from pipes also serve to raise the temperature up to $20^{\circ} \mathrm{C}$. Heat flow through the basement ceiling depends directly on the basement temperature which means that heat losses in the basement can also be partly utilised for decreasing heating energy consumption. Our calculations showed that the potential decrease in delivered energy compared to the potential increase of delivered energy is small and this depends on the thickness of the service pipes thermal insulation and the buildings total delivered heating energy. In buildings where there are large heat losses from the envelope and ventilation, the share of pipe heat losses can be up to $10 \%$ which is almost unnoticeable, but in buildings where the energy efficiency goal is to have, after renovation, optimal heating energy consumption, there can be heat losses from pipes that are up to $30 \%$ with 20 $\mathrm{mm}$ of pipe insulation. From this we can say that service pipe heat losses must be included in energy efficiency calculations.

When pipe losses in an $\mathrm{nZEB}$ are $6.6 \mathrm{kWh} /\left(\mathrm{m}^{2} \cdot \mathrm{a}\right)$, then the decrease from ceiling heat losses is $2.2 \mathrm{kWh} /\left(\mathrm{m}^{2} \cdot \mathrm{a}\right)$ which means that the total increase is $4.4 \mathrm{kWh} /\left(\mathrm{m}^{2} \cdot \mathrm{a}\right)$.

Our analyse showed that in buildings with district heating, the EPV number, with $40 \mathrm{~mm}$ pipe insulation, is at least $4 \mathrm{kWh} /\left(\mathrm{m}^{2} \cdot \mathrm{a}\right)$ and with $20 \mathrm{~mm}$ pipe insulation, 6 $\mathrm{kWh} /\left(\mathrm{m}^{2} \cdot \mathrm{a}\right)$. With longer heating pipelines in the basement, the increase of EPV can be even greater.

Our goal was also to provide energy auditors with a graph from which they can easily take average basement pipe heat losses in situations where they have only measured indoor temperature in the basement. For example, when an EPV class "C" building basement average temperature is, during the period December until the end of February, on average, $14^{\circ} \mathrm{C}$, then the EPV component for pipe losses is, in an average renovated apartment building, $5 \mathrm{kWh} /\left(\mathrm{m}^{2} \cdot \mathrm{a}\right)$.

The impact of service pipe losses in basements has been analysed a few times in earlier studies. Most papers on this have been focused on analysing the efficiency of DHW. Bohm [32] show in his study that DHW efficiency is 0.30 up to 0.77 (heat losses are $23 \%$ up to $70 \%$ ) in apartment buildings. In his calculation, most of the losses comes from DHW circulation losses. A large impact from DHW circulations has also been shown in other studies [33-37]. In our study, most of the pipe losses are also involved with DHW system losses. The proportion of DHW losses from the entire pipe loss is approximately $75 \%$. 


\section{Conclusion}

Our study showed that pipe losses in a typical highly insulated Estonian apartment building with an unheated basement and insulated pipes have a large effect on the EPV value. In apartment buildings with district heating, the difference with, and without pipe losses, to the EPV is at least $4 \mathrm{kWh} /\left(\mathrm{m}^{2} \cdot \mathrm{a}\right)$. From the total delivered heating energy consumption in an nZEB building this is $25 \%$. If the total increase coming from pipe losses in the same situation is $7.1 \mathrm{kWh} /\left(\mathrm{m}^{2} \cdot \mathrm{a}\right)$ but the decrease from internal heat gain in the basement is $2.7 \mathrm{kWh} /\left(\mathrm{m}^{2} \cdot \mathrm{a}\right)$, we find a total increase of delivered heating energy of 4.4 $\mathrm{kWh} /\left(\mathrm{m}^{2} \cdot \mathrm{a}\right)$. Internal heat gain from pipes means that heat flow from the heated zone through the basement ceiling $\left(\mathrm{Ur}=1.4 \mathrm{~W} /\left(\mathrm{m}^{2} \cdot \mathrm{K}\right)\right)$, between December until the end of February, is $6.7 \mathrm{~W} / \mathrm{m}^{2}$, and without pipe losses, $9.0 \mathrm{~W} / \mathrm{m}^{2}$.

The basement average temperature in heating period (16 of October until 14 of April) can also demonstrate just how big the losses from pipes can be, and how this affects the EPV. In existing houses with poorly insulated pipes, the average basement temperature is $16^{\circ} \mathrm{C}$, which means that the EPV can be increased to more than $5 \mathrm{kWh} /\left(\mathrm{m}^{2} \cdot \mathrm{a}\right)$ (Fig. 8).

The results of our analyses are a good base from which to analyse the effect of pipe heat losses in the basement of a typical Estonian apartment building on the building energy efficiency, and our figures can be used to evaluate the impact of pipe losses on its energy efficiency.

This research was supported by the Estonian Centre of Excellence in Zero Energy and Resource Efficient Smart Buildings and Districts, ZEBE (grant No. 2014-2020.4.01.150016) funded by the European Regional Development Fund, by the Estonian Research Council (grant No. PRG483), and by the European Commission through the H2020 project Finest Twins (grant No. 856602).

\section{References}

1. Eurostat, Energy Consumption in Households (2019)

2. J. Kurnitski, T. Kalamees, and T. Tark, in 7th Int. Cold Clim. HVAC Conf. (2012)

3. K. Kuusk and T. Kalamees, Build. Res. Inf. 44, (2016)

4. T. Niemelä, R. Kosonen, and J. Jokisalo, Sustain. Cities Soc. 32, 9 (2017)

5. L. La Fleur, P. Rohdin, and B. Moshfegh, Energy Build. 203, (2019)

6. K. Kuusk and T. Kalamees, Energy Procedia 78, 985 (2015)

7. A. Hamburg and T. Kalamees, Energy Build. (2019)

8. D. Calì, T. Osterhage, R. Streblow, and D. Müller, Energy Build. 127, 1146 (2016)

9. S. Cozza, J. Chambers, and M. K. Patel, Energy Policy 111085 (2019)

10. K. Kuusk, T. Kalamees, S. Link, S. Ilomets, and A. Mikola, J. Civ. Eng. Manag. 23, 67 (2017)
11. A. Hamburg and T. Kalamees, Energies 11, 3179 (2018)

12. L. La Fleur, B. Moshfegh, and P. Rohdin, Energy Build. 146, 98 (2017)

13. S. Ilomets, K. Kuusk, L. Paap, E. Arumägi, and T. Kalamees, J. Civ. Eng. Manag. 23, 96 (2017)

14. L. Evangelisti, C. Guattari, P. Gori, and R. Vollaro, Sustainability 7, 10388 (2015)

15. K. Kuusk, J. Kurnitski, and T. Kalamees, Energy Procedia 132, 27 (2017)

16. G. Desogus, S. Mura, and R. Ricciu, Energy Build. 43, 2613 (2011)

17. EN ISO 13370, Thermal Performance of Buildings - Heat Transfer via the Ground Calculation Methods (Geneva, Switzerland, 2017)

18. P. Pihelo, M. Lelumees, and T. Kalamees, in Int. RILEM Conf. Mater. Syst. Struct. Civ. Eng. Conf. Segm. Moisture Mater. Struct. 22-24 August 2016, Tech. Univ. Denmark, Lyngby, Denmark (2016)

19. P. Pihelo, M. Lelumees, and T. Kalamees, in Energy Procedia (Proceedings of the SBE16 Tallinn and Helsinki Conference in Energy Procedia; Build Green and Renovate Deep, 5-7 October 2016, Tallinn and Helsinki., 2016), pp. 745-755

20. P. Pihelo, T. Kalamees, and K. Kuusk, in Proc. 3rd Int. Conf. Innov. Mater. Struct. Technol. IMST2017, (IOP Publishing Ltd, 27-29.09.2017, Riga, Latvia, 2017)

21. P. Shalin, Modelling and Simulation Methods for Modular Continuous System in Buildings, KTH, Stockholm, Sweden, 1996

22. N. Björsell, A. Bring, L. Eriksson, P. Grozman, M. Lindgren, P. Sahlin, A. Shapovalov, B. Data, and M. Vuolle, in Proc. IBPSA Build. Simul. '99 Conf. (Kyoto, Japan, 1999), pp. 1-8

23. S. Moinard and G. Guyon, Empirical Validation of EDF ETNA and GENEC Test-Cell Models A Report of Task 22 Building Energy Analysis Tools (1999)

24. J. Travesi, G. Maxwell, C. Klaassen, and M. Holtz, Empirical Validation of Iowa Energy Resource Station Building Energy Analysis Simulation Models, IEA Task 22, Subtask A (2001)

25. M. Achermann and G. Zweifel, RADTEST Radiant Heating and Cooling Test Cases, Subtask C. A Report of IEA Task 22. Building Energy Analysis Tools. (2003)

26. A. Hamburg, K. Kuusk, A. Mikola, and T. Kalamees, Energy 116874 (2019)

27. 14 RT I, 13.12.2018, Decree of the Minister of Entrepreneurship and Information Technology $\mathrm{Nr} 63$ (11.12.2018). Energy Performance Requirements of the Buildings (in Estonian: 
Ettevõtlus- Ja Infotehnoloogiaministri Määrus Nr 63 (11.12.2018). Hoone Energiatõhususe Miinimumnõuded (Riigi Teataja, 2018)

28. 13 RT I, 18.01.2019, Decree of the Minister of Economic Affairs and Infrastructure $\mathrm{Nr} 36$, (Redaction 21.01.2019). Requirements for Energy Label Issuing and Energy Labeling (in Estonian: Majandus- Ja Taristuministri Määrus $\mathrm{Nr} 36$ (Redaktsioon 21.01.2019). Nõuded Energiamärgise (Riigi Teataja, 2019)

29. EN 15316-3, Energy Performance of Buildings Method for Calculation of System Energy Requirements and System Efficiencies - Part 3: Space Distribution Systems (DHW, Heating and Cooling), Module M3-6, M4-6, M8-6 (Brussels, 2017)

30. 7 RT I, 19.01.2018, MKM Määrus Nr. 58, Hoonete Energiatõhususe Arvutamise Metoodika (Minister of Economic Affairs and Communications Regulation Nr. 58, Methodology for Calculating the Energy Performance of Buildings) (2018)

31. DIN V 18599, Energetische Bewertung von Gebäuden - Berechnung Des Nutz-, End- Und Primärenergiebedarfs Für Heizung, Kühlung, Lüftung, Trinkwarmwasser Und Beleuchtung (Energy Efficiency of Buildings - Calculation of the Net, Final and Primary Energy Demand (2018)

32. B. Bøhm, Energy Convers. Manag. 67, 152 (2013)

33. T. Cholewa, A. Siuta-Olcha, and R. Anasiewicz, J. Clean. Prod. 217, 194 (2019)

34. Y. Zhang, C. Bonneville, S. Wilson, M. Maroney, J. Staller, and J. Yun Wei, ASHRAE Trans. 118, 357 (2012)

35. A. Marszal-Pomianowska, C. Zhang, M. Pomianowski, P. Heiselberg, K. Gram-Hanssen, and A. Rhiger Hansen, Energy Build. 184, 53 (2019)

36. J. E. Thorsen and T. S. Ommen, in 16th Int. Symp. Dist. Heat. Cool. DHC2018 (9-12 September 2018, Hamburg, Germany, 2018), pp. 197-205

37. K. Zvaigznitis, C. Rochas, G. Zogla, and A. Kamenders, Energy Procedia 72, 245 (2015) 